\title{
Economic impact of climate change on Nigerian maize sector: a Ricardian analysis
}

\author{
P. I. Ater \& G. C. Aye \\ Department of Agricultural Economics, University of Agriculture, \\ Makurdi, Nigeria
}

\begin{abstract}
This paper evaluates the economic impact of climate change on Nigeria's maize sector using a Ricardian approach. Data was collected on temperature, precipitation, soil, maize revenue, socioeconomic characteristics and adaptation strategies to varying climate factors. The study reveals that net maize revenue per hectare is sensitive to climate change. The impact of predicted climate scenarios from three models (CGM2, HADCM3 and PCM) indicated that there would be an increasing reduction in maize net revenue per hectare over the forecast period unless appropriate mitigation responses are adopted. Further, impact of climate change is not uniformly distributed across the different agroecological zones.
\end{abstract}

Keywords: climate change, temperature, precipitation, maize, Nigeria, Ricardian analysis.

\section{Introduction}

There is a growing consensus that the world is warming and will continue to warm as the concentration of greenhouse gases rise in the future (IPCC [1]). Although agricultural production, including access to food, in many African countries and regions is projected to be severely compromised by climate variability and change, country and crop specific impacts are limited. This paper examines the climate sensitivity of agricultural production in Nigeria. Agriculture plays a cardinal role in Nigeria's economy contributing the greatest share $(40.9 \%)$ to the nation's real gross domestic production in 2010 (CBN [2]). Further, agriculture generates employment for over 70 percent of the total labour force, accounts for about 60 percent of the non-oil exports and provides over 80 
percent of the food needs of the country (Onwuemenyi [3] and CBN [4]). Farmers are already highly vulnerable because of high current temperatures and poverty. Slightly above half of the population (51.6 percent) live below US\$1 dollar per day and the relative national poverty incidence was found to be 54.4 percent (NBS [5]). This poverty situation is worse in the rural areas where over 70 percent of the people reside and earn their living through agriculture. There is much concern about small household farms because these farms tend to be poor with few technological alternatives.

Economic impact of climate change may vary from one enterprise to another. Therefore, it is important to conduct enterprise specific analysis. Against this background, this study measures the impact of climate on Nigerian smallholder maize farm households using a Ricardian analysis. To the best of my knowledge, there is no study on the economic impact of climate change on maize production in Nigeria. Maize is one of the main staple crops in Nigeria and featured among the five food crops (cassava, maize, wheat, rice and sugar) whose production is to be promoted for attainment of food self-sufficiency.

The Ricardian method is briefly reviewed in section 2. Results of the Ricardian analysis and climate forecasts are discussed in section 3. The paper concludes with a summary of the empirical results and the results of the climate forecasts. The policy implications of the results are also discussed.

\section{Methodology}

The econometric approach used in this study is based on the Ricardian method. The theoretical basis of this method is deeply rooted in the famous theory of 'economic rents' by David Ricardo (1772-1823). The model is named after him because of his original observation that the value of land would reflect its net productivity. However, much of its application to climate-land value analysis draws extensively from Mendelsohn et al. [6]. The Ricardian method is a crosssectional approach to studying agricultural production. The greatest advantage of this empirical approach is that the method not only includes the direct effect of climate on productivity but also the adaptation response by farmers to local climate. Despite these major advantages that the Ricardian method has over alternative climatic impact models such as the Production Function Model (PFM), the Agronomic-Economic Models (AEM) and the Agro-Ecological Zone Model (AEZM), it has been extensively criticized on grounds that (i) crops are not subject to controlled experiments across farms as the case with the AEM and AEZM, (ii) it does not account for future changes in technology, policies and institutions, (iii) the model assumes constant prices which is really the case with agricultural commodities since other factors determine prices; and, (iv) it fails to account for the effect of factors that do not vary across space such as carbon dioxide concentrations (Mendelsohn et al. [7] and Hassan [8]).

Despite its major short comings, the Ricardian method has been extensively applied in both the developed and developing countries to predict the damages from climate change with remarkable success (see for example [7-23]). 
Farmland net revenues $(\mathrm{R})$ reflect net productivity. This principle is captured in the following equation:

$$
R=\sum P_{i} Q_{i}(X, F)-\sum P_{x} X
$$

where $P_{i}$ is the market price of crop i, $Q_{i}$ is the output of crop i, $X$ is a vector of purchased inputs (except land), $F$ is a vector of climate variables, $Z$ is a vector of other control variables such as soil, water source, educational level etc, and $P_{x}$ is a vector of input prices (see Mendelsohn et al. [7]). The farmer is assumed to choose $X$ to maximize net revenues given the characteristics of the farm and market prices. The Ricardian model is a reduced form model that examines how several exogenous variables, $F$ and $Z$, affect net revenues.

Following previous works, the Ricardian model relies on a quadratic formulation of climate (temperature and precipitation). We adopt the loglinear form of the model:

$$
\ln R=\beta_{0}+\beta_{1} F+\beta_{2} F^{2}+\beta_{3} Z+\varepsilon .
$$

where $\beta$ is estimated coefficient and $\varepsilon$ is an error term. $\ln$ is the natural logarithm. The expected marginal impact of a single climate variable on farm net revenue evaluated at the mean is:

$$
E\left[\frac{d R}{d f_{i}}\right]=R *\left(\beta_{1, i}+2 * \beta_{2, i} * E\left[f_{i}\right]\right) .
$$

The marginal value of climate depends upon the level of climate $\left(f_{i}\right)$. For example, the marginal value of temperature will depend upon how warm the farm is already. With a quadratic formulation, not only can the magnitude of the marginal effect change, but also the sign. The quadratic term reflects the nonlinear shape of the net revenue climate response function (eqn (2)). When the quadratic term is positive, the net revenue function is U-shaped and when the quadratic term is negative, the function is hill-shaped. Based on agronomic research and previous cross-sectional analyses, that farm value is expected to have a hill-shaped relationship with temperature. For each crop, there is a known temperature at which that crop grows best across the seasons. The relationship of seasonal climate variables, however, is more complex and may include a mixture of positive and negative coefficients across seasons.

The loglinear functional form assumes that climate impacts are proportional to net revenue. The change in annual welfare, $\Delta W$ resulting from a climate change from $C_{0}$ to $C_{1}$ can be measured as follows:

$$
\Delta W=R\left(C_{1}\right)-R\left(C_{0}\right) .
$$

Changes that increase net revenue are beneficial and changes that decrease net revenue are harmful. This is a comparative static analysis. It is not a dynamic model. The Ricardian model is not measuring the effects of year-to-year changes in weather but rather long-term changes in climate. 
Socioeconomic and demographic data to estimate the model come from the 2004 Nigeria Household Survey. This survey provides detailed data on assets, socio-demographic characteristics, production, water source among others. Meteorological data was obtained from World data centre. The data included monthly temperature and precipitation from ten weather stations (Enugu, Ilorin, Jos, Kano, Lagos, Maiduguri, Makurdi, Minna, Portharcourt, Yola) in Nigeria for 1961-1990. The soil data was obtained from Food and Agricultural Organization. Five soil types were identified; hence the soil variable was coded 1-5. Several climate combinations were explored but the winter (December February), spring (March - May), summer (June - August) and fall (September November) average precipitation and temperature definitions were found to have the best fit.

\section{Results}

The results from both the Ricardian regression model and the projections from climate scenarios are presented in this section.

\subsection{Regression estimates and marginal impacts from the Ricardian model}

The mean of the variables used in the analysis is reported in table 1 . The mean net revenue per hectare from maize farm is $\$ 32935.69$ (i.e. US\$204.57). The mean temperature ranges from $29.8^{\circ} \mathrm{C}$ to $34.3^{\circ} \mathrm{C}$. This is quite high. The mean

Table 1: $\quad$ Summary statistic of variables used in the analysis.

\begin{tabular}{|l|l|l|}
\hline Variables & Mean & Standard \\
\hline Net revenue (Naira/ha) & 32935.692 & 5737.647 \\
\hline Winter precipitation $(\mathrm{mm} / \mathrm{mo})$ & 10.056 & 12.832 \\
\hline Spring precipitation $(\mathrm{mm} / \mathrm{mo})$ & 100.078 & 51.986 \\
\hline Summer precipitation $(\mathrm{mm} / \mathrm{mo})$ & 215.037 & 54.559 \\
\hline Fall precipitation $\left({ }^{\circ} \mathrm{C}\right)$ & 114.726 & 56.738 \\
\hline Winter temperature $\left({ }^{\circ} \mathrm{C}\right)$ & 33.296 & 2.399 \\
\hline Spring temperature $\left({ }^{\circ} \mathrm{C}\right)$ & 34.293 & 3.008 \\
\hline Summer temperature $\left({ }^{\circ} \mathrm{C}\right)$ & 29.770 & 2.371 \\
\hline Fall temperature $\left({ }^{\circ} \mathrm{C}\right)$ & 31.430 & 2.112 \\
\hline Soil type $($ score $)$ & 3.000 & 1.000 \\
\hline Water source $(\%)$ & 31.033 & 11.515 \\
\hline Age (years) & 47.444 & 5.003 \\
\hline Education $($ years) & 7.258 & 15.395 \\
\hline Household size $(\#)$ & 4.678 & 0.492 \\
\hline Tenure $(\%)$ & 21.938 & 7.894 \\
\hline Improved variety $(\%)$ & 13.400 & 7.027 \\
\hline Credit $(\%)$ & 11.844 & 4.369 \\
\hline Market $(\mathrm{km})$ & 53.111 & 27.061 \\
\hline
\end{tabular}


precipitation ranges from $10 \mathrm{~mm} / \mathrm{mo}$ to $215 \mathrm{~mm} / \mathrm{mo}$. The average farm household has about five members. The average education of the head of household is about 7 years. The average age of farmers is 47 years. About $13 \%$ of farm households used improved seedlings. About 22\% own the land on which they farm.

The regression coefficients from the Ricardian model are presented in table 2 . Most of the climate variables are significant. In most cases, net revenue maintained a hill-shaped relationship with temperature but a U-shaped relationship with precipitation. Precipitation plays a large role in determining whether farmers choose irrigation or not. About 31\% of farm households cited river as their major water source and this variable was found significant.

Table 2: $\quad$ Regression estimates of the Ricardian model.

\begin{tabular}{|c|c|c|}
\hline Variable & Coefficient & T-ratio \\
\hline Winter precipitation & -0.027 & 4.182 \\
\hline Winter precipitation squared & 0.000 & 2.497 \\
\hline Spring precipitation & -0.123 & 3.664 \\
\hline Spring precipitation squared & 0.001 & 3.123 \\
\hline Summer precipitation & -0.015 & 1.552 \\
\hline $\begin{array}{l}\text { Summer } \\
\text { squared }\end{array}$ & 0.001 & 2.831 \\
\hline Fall precipitation & 0.081 & 2.691 \\
\hline Fall precipitation squared & 0.000 & 0.727 \\
\hline Winter temperature & 0.112 & 2.774 \\
\hline Winter temperature squared & -0.002 & 3.124 \\
\hline Spring temperature & -0.786 & 6.583 \\
\hline Spring temperature squared & -0.007 & 4.003 \\
\hline Summer temperature & 2.127 & 3.626 \\
\hline $\begin{array}{l}\text { Summer temperature } \\
\text { squared }\end{array}$ & 0.022 & 1.978 \\
\hline Fall temperature & -2.589 & 3.222 \\
\hline Fall temperature squared & -0.020 & 0.884 \\
\hline Soil type & -0.360 & 1.284 \\
\hline Water source & 0.056 & 2.031 \\
\hline Age & -0.020 & 3.115 \\
\hline Education & 0.048 & 1.963 \\
\hline Household size & 1.368 & 1.537 \\
\hline Tenure & 0.001 & 2.450 \\
\hline Improved variety & 0.002 & 3.670 \\
\hline Credit & -0.168 & 3.015 \\
\hline Market & -0.001 & 2.931 \\
\hline Constant & 5.001 & 2.012 \\
\hline Adjusted $\mathrm{R}^{2}$ & 0.74 & \\
\hline
\end{tabular}


Younger farmers earn more revenue from maize farming than older farmers. This is because younger farmers are more likely to comprehend the complexities of new technologies than older farmers. Farmers with higher level of education earn more net revenue than illiterate farmers. Market is a proxy for good infrastructure. The farther away from the capital city, the lower the net revenue per hectare. Access to credit is significant but negative. It is expected that having access to capital would be desirable. However, this variable actually measures the presence of loans amongst farmers and may be correlated with low net revenues and therefore endogenous. Holding ownership to a land is an incentive to greater investment in land. In this study the variable tenure is positively related to net revenue. Use of improved varieties is also positively related to net revenue.

Table 3 calculates the marginal impact of climate for each of the climate location in our analysis. The impact of winter precipitation was essentially negative in all the locations with exception of Lagos and Port Harcourt. The harmful winter precipitation impact ranges from $-1.677(-0.01 \%)$ to -67.551 $(-0.28 \%)$ naira per $\mathrm{mm} / \mathrm{mo}$ evaluated at the sample mean. The spring, summer and fall precipitations are beneficial in all locations but with varying magnitudes.

Table 3: $\quad$ Marginal impact of climate change on net revenue by location.

\begin{tabular}{|c|c|c|c|c|}
\hline & Winter & Spring & Summer & Fall \\
\hline \multicolumn{5}{|c|}{ Precipitation } \\
\hline ENUGU & -1.676 & 766.302 & 366.407 & 862.687 \\
\hline ILORIN & -17.241 & 504.871 & 244.883 & 654.760 \\
\hline JOS & -61.734 & 418.328 & 397.561 & 511.393 \\
\hline LAGOS & 40.301 & 805.968 & 340.725 & 627.185 \\
\hline MAIDUGURI & -67.394 & -196.487 & 205.929 & 325.684 \\
\hline MAKURDI & -57.017 & 433.009 & 306.734 & 632.673 \\
\hline MINNA & -56.703 & 228.243 & 326.946 & 648.487 \\
\hline $\begin{array}{l}\text { PORT } \\
\text { HARCOURT }\end{array}$ & 107.905 & 1129.730 & 469.593 & 1102.764 \\
\hline YOLA & -67.551 & 86.065 & 247.771 & 506.950 \\
\hline \multicolumn{5}{|c|}{ Temperature } \\
\hline ENUGU & -118.102 & -3177.918 & 8699.834 & -9674.494 \\
\hline ILORIN & -125.191 & -3206.807 & 8673.535 & -9698.201 \\
\hline JOS & -46.823 & -3039.490 & 8162.581 & -9264.712 \\
\hline LAGOS & -101.956 & -3126.158 & 8557.067 & -9559.349 \\
\hline MAIDUGURI & -108.257 & -3382.551 & 9150.676 & -10023.317 \\
\hline MAKURDI & -136.218 & -3229.678 & 8759.946 & -9738.840 \\
\hline MINNA & -137.399 & -3241.715 & 8662.264 & -9755.774 \\
\hline $\begin{array}{l}\text { PORT } \\
\text { HARCOURT }\end{array}$ & -103.532 & -3127.362 & 8617.180 & -9562.736 \\
\hline YOLA & -135.430 & -3348.847 & 8917.741 & -9881.079 \\
\hline
\end{tabular}


The model suggests that with exception of summer temperature, all other seasons' temperatures are harmful to maize revenue in all the climate locations. The negative temperature impacts range from $-46.823(-0.15 \%)$ to $-10,023.32$ $(-28.56 \%)$ naira per degree Celsius evaluated at the mean of the sample. The harmful temperature effects are largely due to fall and spring temperatures.

\subsection{Projections with climate scenarios}

The estimated regression in the previous section was used to explore how future climate change scenarios might affect maize in Nigeria. The Ricardian results prove that net revenue vary across existing climates in Nigeria. The marginal impacts imply that a small change in temperature would have immediately harmful effects on Nigerian agriculture. Moving forward from here, we now wish to explore the magnitude of impacts if climate changes a great deal. We use the estimated Ricardian functional forms to predict how future climates might affect future maize net revenue. These projections assume that all other conditions are held constant. Therefore, we are not making a forecast of how net revenue of maize will actually change. We are simply isolating the effect of climate change on net revenue of maize. We examine a set of climate change scenarios for 2100 predicted by three climate models: The Canadian General Circulation Model (CGM2), Hadley Centre for Climate Prediction and Research (HADCM3), and the Parallel Climate Model (PCM).

Table 4 presents the predictions from each climate scenario. The regression in table 1 is used to predict impacts for the whole sample. Losses were limited to the net revenue of the farm. That is, the most a farm can lose is $100 \%$ of its net revenue. The CGM2 scenario predicts a loss of $63 \%$ of net revenue. The HADCM3 predicts a loss of $56 \%$ of net revenue. The smallest losses were associated with the milder PCM scenario (-42\%). Although the sample of all farms lost about half of its net revenue, some farms lost all of their net revenue. The effects based on the climate scenarios vary from one climate location to the other, though these results are not reported here.

Table 4: Forecasted welfare impacts of alternative climate scenarios for 2100 .

\begin{tabular}{|l|l|r|}
\hline Scenario & Change in net revenue & $\begin{array}{l}\text { \% change in net } \\
\text { revenue }\end{array}$ \\
\hline CGM2 & -15005.5248 & -63.3836 \\
\hline HADCM3 & -13245.0758 & -55.9475 \\
\hline PCM & -10026.89 & -42.3538 \\
\hline
\end{tabular}

\section{Conclusion and policy implications}

In this study we evaluated the impact of climate change on maize net revenue. The analysis shows that maize net revenue in Nigeria is sensitive to climate. A marginal increase in annual temperature reduces net revenue by -46.823 
$(-0.15 \%)$ to $-10,023.32(-28.56 \%)$ naira per degree Celsius evaluated at the mean of the sample. However, this harmful effect is due largely to the negative consequences of spring and fall temperatures. A marginal increase in precipitation in the winter season is predicted to decrease net revenue of maize. Future climate scenarios paint a bleak picture for Nigerian agriculture. The loglinear model predicts average losses between $42 \%$ and $63 \%$. Projections of future impacts suggest that the impacts will vary a great deal across the Nigerian landscape. Locations in the Northern part with exception of Jos are more vulnerable to warming than locations in the South.

Managing water more efficiently may help as part of a larger strategy to make irrigation more effective in Nigeria. Thus, providing farmers with more secure property rights to their water and lands may help provide incentive for farmers to invest more heavily in irrigated farming. Providing micro credit may help especially poorer farm households make needed investments into capital to improve their farms. The use of conservation technologies may also abate the harmful effects of extreme temperatures. Producing more effective varieties that might be more suited for a warmer climate may provide farmers with useful substitutes for current crops. In summary, this study has revealed the critical need for abatement, adaptation and compensation.

\section{References}

[1] Intergovernmental Panel on Climate Change, Climate Change 2007: Synthesis Report. http://www.ipcc.ch/pdf/assessment-report/ar4/syr/ ar4_syr.pdf

[2] Central Bank of Nigeria, Annual report, 2010. http://www.cenbank.org/ documents/cbnannualreports.asp

[3] Onwuemenyi, O., Taking agriculture to commercial status in Nigeria. The Punch, Sunday, 21 $1^{\text {st }}$ Sept, 2008. http://www.punchng.com/ Articl.aspx?theartic $=$ Art200809210172931

[4] Central Bank of Nigeria, Annual report and statement of accounts, for the year ended $31^{\text {st }}$ December, 2008. http://www.cenbank.org/documents/ cbnannualreports.asp

[5] National Bureau for Statistics, Facts and figures about Nigeria, 2008. http://www.nigerianstat.gov.ng

[6] Mendelsohn, R., Nordhaus, W. and Shaw, D., The impact of global warming on agriculture: A Ricardian analysis. American Economic Review, 84, pp. 753-771, 1994.

[7] Mendelsohn, R., Arellano-Gonzalez, J. and Christensen, P., A Ricardian analysis of Mexican farms. Environment and Development Economics, 15, pp. 153-171, 2009.

[8] Hassan,R. (2010). Implications of climate change for agricultural sector performance in Africa: policy challenges and research agenda. Journal of African Economies, 19, Supplement 2, pp. 77-105. 
[9] Mendelsohn, R. and Dinar, A., Climate change, agriculture, and developing countries: Does adaptation matter? The World Bank Research Observer, 14(2), pp. 277-293, 1999.

[10] Mendelsohn, R. and Dinar, A., Climate, water, and agriculture. Land Economics, 79(3), pp. 328-341, 2003.

[11] Kumar, K. and Parikh, J., Indian agriculture and climate sensitivity. Global Environmental Change, 11, pp. 147-154, 2001.

[12] Chang, C.C., The potential impact of climate change on Taiwan's agriculture. Agricultural Economics, 227, pp. 51-64, 2002.

[13] Gbetibouo, G. and Hassan, R., Measuring the economic impact of climate change on major South African field crops: a Ricardian approach. Global and Planetary Change, 47(2-4), pp. 143-152, 2005.

[14] Hassan, R. and Nhemachena, C., Determinants of climate adaptation strategies of African Farmers: multinomial choice analysis. African Journal of Agricultural and Resource Economics, 2(1), pp. 83-104, 2008.

[15] Deressa, T., Hassan, R. and Poonyth, D., Measuring the economic impact of climate change on South Africa's sugarcane growing regions. Agrekon, 44(4), pp. 524-542, 2005.

[16] Seo, S.O., Mendelsohn, R., and Munasinghe, M., Climate change and agriculture in Sri Lanka: a Ricardian valuation. Environment and Development Economics, 10, pp. 581-596, 2005.

[17] Mendelsohn, R. 2007. Measuring climate impacts with cross sectional analysis. Climate Change, pp. 81: 1-7, 2007.

[18] Seo, N. and Mendelsohn, R. A Ricardian analysis of the impact of climate change on South American farms. Chilean Journal of Agricultural Research 68, pp. 69-79, 2008a.

[19] Seo, N. and Mendelsohn, R., Climate change impacts and adaptations on animal husbandry in Africa. African Journal Agriculture and Resource Economics, 2, pp. 65-82, 2008b.

[20] Seo, N. and Mendelsohn, R., An analysis of crop choice: adapting to climate change in Latin American farms. Ecological Economics, 67, pp. 109-116, 2008c.

[21] Deressa, T.T. and Hassan, R.M., Economic impact of climate change on crop production in Ethiopia: evidence from cross-section measures. Journal of African Economies, 18(4), pp. 529-554, 2009.

[22] Ajetomobia J., Abiodun, A. and Hassan, R., Impacts of climate change on rice agriculture in Nigeria. Tropical and Subtropical Agroecosystems, 14, pp. 613-622, 2011.

[23] Fonta, W.M.., Ichoku, H. E., and Urama, N.E., Climate change and plantation agriculture: a Ricardian analysis of farmlands in Nigeria. Journal of Economics and Sustainable Development, 2(4), pp. 63-75, 2011. 